\title{
Aztec and Tlaxcalan Economic Interaction: Blockade or Interregional Exchange?
}

\author{
Bianca L. Gentil (D), A. Gabriel Vicencio Castellanos, and Kenneth G. Hirth
}

\begin{abstract}
This study investigates the impact of the Aztec Triple Alliance on trade and economic activity in the region of Puebla-Tlaxcala during the Late Postclassic period (AD 1200-1519). Ethnohistorical sources describe the Aztec Triple Alliance as constantly at war with settlements in the Tlaxcala region. To weaken their Tlaxcalteca rivals, the Aztecs imposed a trade blockade to reduce the flow of resources into Puebla-Tlaxcala. This article uses archaeological evidence to evaluate the effectiveness of this blockade. It compares the types of obsidian used to manufacture lithic tools from Aztec-controlled sources with those used within Puebla-Tlaxcala. Information from the large center of Tepeticpac and the small obsidian workshop site of Cinco Santos II, both in the Tlaxcala domain, are compared to other sites in Central Mexico prior to and during the height of Aztec influence. The results show little difference in regional trade patterns: obsidian from Sierra de las Navajas and Otumba was used in proportions in the Tlaxcala region in the Late Postclassic similar to those used during earlier periods. If an embargo was attempted, it was largely unsuccessful in isolating Tlaxcala from broader regional distribution networks.
\end{abstract}

Keywords: Mesoamerica, Tlaxcala, obsidian, exchange networks, Late Postclassic

Este estudio investiga la influencia de Triple Alianza Azteca en el intercambio y la economía dentro de la región PueblaTlaxcala durante el Posclásico Tardío (1200-1519 dC). Fuentes etnohistóricas describen a la Triple Alianza Azteca en constantes guerras con asentamientos en la región de Tlaxcala. Con el fin de debilitar a sus rivales tlaxcaltecas, los Aztecas impusieron un bloqueo para reducir la afluencia de recursos a la región enemiga. Este trabajo evalúa esta presunción. Se compararon los tipos de obsidiana proveídos por yacimientos controlados por los Aztecas, y aquellas obsidianas usadas en dos asentamientos tlaxcaltecas dentro de la región Puebla-Tlaxcala. La información obtenida del gran altepetl de Tepeticpac y un pequeño taller de obsidiana localizado en el sitio de Cinco Santos II serán comparados con sitios ubicados en el Centro de México antes y durante el apogeo de la influencia Azteca. Los resultados revelan pocos cambios en los patrones de intercambio regionales: la obsidiana de Sierra de las Navajas y Otumba fue utilizada en proporciones similares en la región de Tlaxcala durante el Posclásico Tardío, como también en los periodos anteriores. Si hubo algún intento de embargo, éste no pudo aislar a Tlaxcala de redes de intercambio más amplias.

Palabras claves: Mesoamérica, Tlaxcala, obsidiana, rutas de intercambio, Posclásico tardío

I n AD 1428, the Culhua-Mexica people, commonly known as the Aztecs, revolted from their Atzcapotzalco overlords and began their conquests of the Basin of Mexico. Izcoatl, the Mexica huetlatoani, joined with the rulers of Tezcoco and Tlacopan in a political confederacy known today as the Aztec Triple Alliance.
Under Mexica leadership, this alliance conquered a large area of Mexico (Figure 1) and forged a tribute empire stretching from the Gulf to the Pacific coasts, southeast into Oaxaca, and into parts of coastal Guatemala (Berdan 2014; Hassig 1988). Although this empire encompassed most of Central Mexico, it did not include

Bianca L. Gentil (bug156@psu.edu, corresponding author) and Kenneth G. Hirth $\mathbf{\square}$ Department of Anthropology, Pennsylvania State University, 312 Carpenter Building, University Park, PA 16802, USA

A. Gabriel Vicencio Castellanos $\mathbf{a}$ Instituto de Investigaciones Antropológicas, Universidad Nacional Autónoma de México, Cto. Exterior, C.U., Coyoacán, 04510 Ciudad de México, CDMX, México

Latin American Antiquity 32(4), 2021, pp. 723-740

Copyright (C) The Author(s), 2021. Published by Cambridge University Press on behalf of the Society for American Archaeology. This is an Open Access article, distributed under the terms of the Creative Commons Attribution licence (http://creativecommons.org/licenses/by/4.0/), which permits unrestricted re-use, distribution, and reproduction in any medium, provided the original work is properly cited.

doi:10.1017/laq.2021.31 


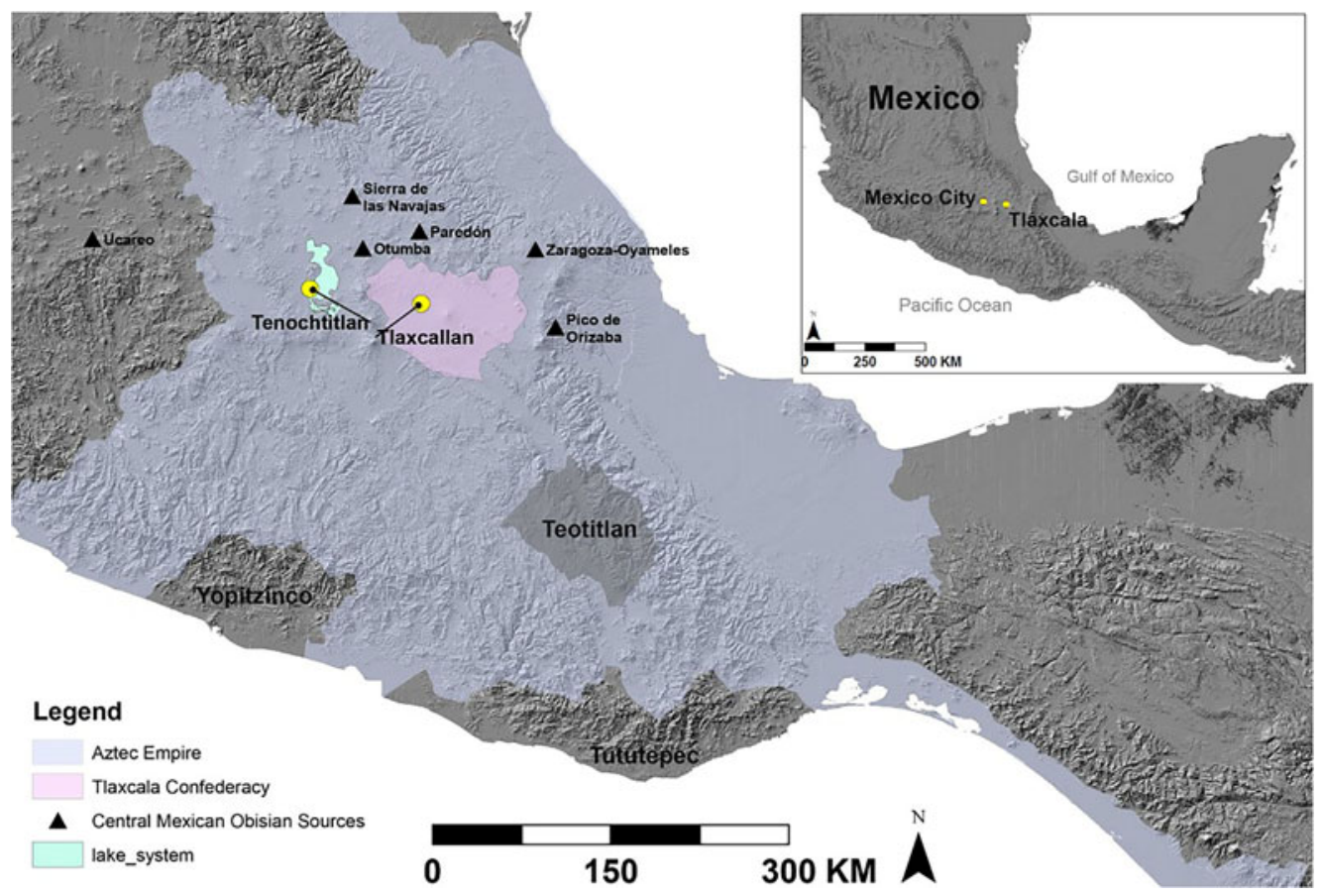

Figure 1. Mexico, the extent of the Aztec Empire, obsidian sources discussed in the text, and independent regions. (Color online)

the neighboring polities of Tlaxcala, Huexotzinco, and Cholula located in the PueblaTlaxcala Valley, which had their own tumultuous history of volatile alliances and interpolity enmities (Ixtlixóchitl 1965 [ca. 1600]). Despite friction, these polities managed to remain relatively autonomous and resisted Aztec incursions into the region through a combination of détente, strong military resistance, and economic independence (Cortés 2001 [1520s]; Evans 2008; Isaac 1983; López et al. 2016). One of the most formidable Aztec adversaries was the Tlaxcala confederacy, an alliance of 17 Nahua and Otomí towns that maintained their independence until the arrival of the Spanish in AD 1519 (Aguilera 1991:54; Cortés 2001 [1520s]:59, 68, 74; Fargher et al. 2017; García Cook 1981; Isaac 1983; López and Santacruz 2010; Muñoz Camargo 1892 [1576-1595]:54, 110-113). The towns within this confederacy supported Hernan Cortés in his campaign against the Aztecs, leading to their defeat in AD 1521.

The presence of a dangerous enemy only $100 \mathrm{~km}$ east of the Aztec capital of Tenochtitlan was an anomaly within the Aztec Empire (Figure 1).
When Motecuhzoma II (the Aztec huetlatoani) and his captains were asked by the Spanish why they did not conquer the Tlaxcala confederacy, they replied, "We could easily do so; but then there would remain nowhere for the young men to train [militarily], except far from here; and, also, we wanted there to always be [nearby] people to sacrifice to our gods" (Andrés de Tapia 1866 [1500s]:752). This reference to military training refers to the scheduled conflicts known as the "Flowery Wars" (Aguilera 1991:42-44; del Castillo 1904 [1568]:291; Durán 1994 [1558?]:402; Ixtlixóchitl 1965 [ca. 1600]:206207; Muñoz Camargo 1892 [1576-1595]:123; Tezozómoc 1878 [1598]:490). The accuracy of Motecuhzoma's characterization of the Aztecs' relationship with Tlaxcala is certainly questionable. The Tlaxcaltecas were formidable opponents (del Castillo 1904 [1568]:181; Cortés 2001 [1520s]:59-60) and were geographically well positioned for defense (Aguilera 1991:26; Muñoz Camargo 1892 [1576-1595]:111-112).

Although tensions between the PueblaTlaxcala polities and the Mexica were likely of long standing, it was Motecuhzoma I 
(AD 1440-1469) who decided to wage "perpetual war" against Huexotzinco, Cholula, and Tlaxcala (Durán 1994 [1558?]:233). Motecuhzoma I conquered Otomí territories north of Tlaxcala, as well as the area surrounding the Puebla-Tlaxcala Valley (Muñoz Camargo 1892:109). In addition to military hostilities, ethnohistorical sources indicate that the Aztecs imposed an economic embargo against Tlaxcala (Berdan 2014; Bueno 2012; Fargher et al. 2010; Millhauser et al. 2015; Muñoz Camargo 1892 [1576-1595]:111). The challenge for archaeologists, which we undertake here, is to determine if this embargo took place and, if so, whether it was effective. Accomplishing that task requires identifying temporally sensitive archaeological collections of restricted goods that correspond to the period when the embargo was said to have been imposed.

No document states the precise date when economic restrictions began, and some sources discuss occasional "truces" between the Aztecs and Tlaxcala (Durán 1994 [1558?]:332; Muñoz Camargo 1892 [1576-1595]:111-112). Given the circumstances of Motecuhzoma I's reign and the known tensions between these two regions, it is possible that economic restrictions were initiated as early as AD 1446. Economic pressure is believed to have increased in the year of 1 Rabbit (AD 1454) following the Great Famine and the start of the Flowery Wars (Aguilera 1991:39; Durán 1994 [1558?]:233-238; Isaac 1983; Muñoz Camargo 1892 [15761595]:110-112). Tezozómoc (1878 [1598]:362 363) describes Motecuhzoma I's speech to his adviser Tlacaelel as conveying that he wished to inflict a "cruel war" on the Tlaxcaltecas, sell them as slaves, sacrifice them to the gods, and extract tribute.

Ethnohistorical sources (Cortés 2001 [1520s]: 66; del Castillo 1904 [1568]:194, Muñoz Camargo 1892 [1576-1595]:111) state that Motecuhzoma I imposed an economic blockade or embargo on Tlaxcala to restrict access to a range of necessities and luxury products for 60 years. The list of embargoed resources includes salt, cotton, tropical feathers, pigments, gold, silver, cacao, and other unspecified goods (Muñoz Camargo 1892 [1576-1595]: 111). Obsidian is not on the list of embargoed items, but we believe it would have been important to include, as discussed later in the article.

How effective this blockade was is unclear, given that Cortés (2001 [1520s]:67-68) reported that the Tlaxcalan center of Ocotelulco had a large marketplace where 30,000 people met daily to trade a range of commodities. Prior to the Aztec embargo, Muñoz Camargo (1892 [1576-1595]:105) described the importation of goods, including cacao, gold, parrot feathers, wax, honey, and cotton, into Tlaxcala from across Mesoamerica. Nevertheless, after the Aztecs conquered Tepeaca, which was located at the eastern entrance to the Puebla-Tlaxcala Valley (Figure 2), Motecuhzoma II stipulated that a great marketplace be built there, "so that all the merchants in the land may trade there" (Durán 1994 [1558?]:159). The goods listed as sold there included a wide range of high-value goods, which probably was a strategic move to draw merchants away from marketplaces in Tlaxcala.

Although the existence of the trade embargo has been accepted in discussions of AztecTlaxcala interaction (Berdan 2014; Fargher et al. 2010), it has not been evaluated using archaeological data because of its short duration: the trade blockade probably lasted only 65 years (AD 1449-1519). It is difficult to isolate archaeological assemblages to that short of a period, even when using high-precision AMS dating. Despite this difficulty, we attempted a preliminary evaluation of Aztec-Tlaxcala trade relations. Research at several sites within Tlaxcala provided new information to assess whether the proposed blockade effectively reduced the flow of important resources, such as obsidian, into the region (Gentil 2018; López et al. 2020; Vicencio 2015, 2019; Xiuhtecutli 2018). An economic blockade would have been difficult to enforce without close monitoring by Aztec authorities, given the permeability of political boundaries and the presence of a buffer zone of Otomí communities located between Aztec and Tlaxcala territories (Aguilera 1991:54; Cortés 2001 [1520s]:221, 223: Durán 1994 [1558?]:273, 344; García Cook 1981; Muñoz Camargo 1892 [1576-1595]:54, 111-113). If it did exist, one would expect obsidian to have been high on the list of restricted goods, because it was vital for military arms and everyday domestic use. 


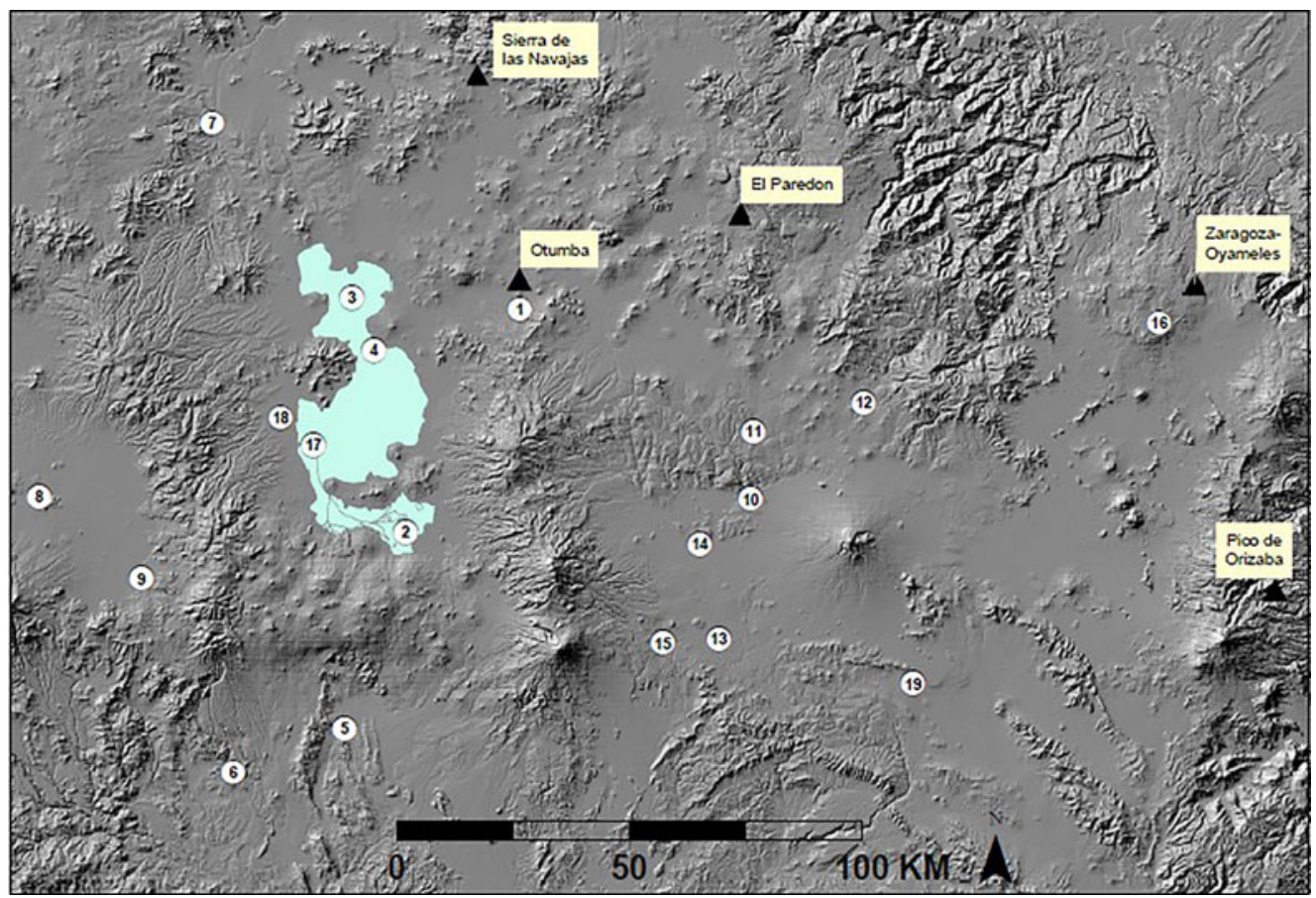

Figure 2. Map highlighting obsidian sources and sites discussed in the text. 1. Cihuatecpan; 2. Chalco; 3. Xaltocan; 4. Chiconautla; 5. Yautepec; 6. Capilco, Xochicalco, and Cuexcomate; 7. Tula and Cerro Magoni; 8. Calixtlahuaca; 9. Santa Cruz Atizapan; 10. Tlaxcallan (Tepeticpac, Tizatlan, Quiahuixtlan, and Ocotelulco); 11. Cinco Santos II and Tlispan; 12. La Laguna; 13. Cholula; 14. Cacaxtla-Xochitecatl; 15. Nealtican and Tetimpa; 16. Cantona; 17. Tenochtitlan; 18. Azcapotzalco; and 19. Tepeaca. (Color online)

We used geochemical sourcing and technological analysis to evaluate whether obsidian from the Aztec-controlled sources of Sierra de las Navajas (Hidalgo) and Otumba (Mexico) entered Tlaxcala in diminished quantities during the Late Postclassic compared to earlier time periods (Figure 3). These two obsidian sources are located within the Aztec tribute domain, and both ethnohistorical sources and archaeological information indicate they were heavily used by communities under Aztec control (Earle and Smith 2012; Elam et al. 2008; Elson 1999; Golitko and Feinman 2015; Hirth and Nichols 2017; Huster 2016; Millhauser 2005; Pastrana 1998, 2004; Pastrana and Carballo 2017). We begin with a brief discussion of the methods used to identify obsidian sources and production technology explored in this study. We then examine obsidian distribution and consumption patterns across Central Mexico preceding and during the Late Postclassic. Although this comparison lacks precision due to the uneven way that obsidian source determinations have been reported, it provides a framework for evaluating continuity or change in the obsidian sources recovered at sites in Tlaxcala during the Late Postclassic. In many cases, reports do not specify obsidian sources beyond the visual identification of green or gray obsidian. Green obsidian is presumed to originate from the Sierra de las Navajas source near Pachuca, even though there may be other sources of green-tinged obsidian in Central Mexico, such as Tulancingo (Pastrana and Carballo 2017:332).

We then examined two contact period sites in Tlaxcala: Tepeticpac and Cinco Santos II. Tepeticpac was one of the main altepemeh (centers) of the Tlaxcalan confederacy (Fargher et al. 2010, 2011; López et al. 2016; López and Santacruz 2010; Muñoz Camargo 1892 [1576-1595]:99, $103,112-113$ ), and the data there are derived primarily from domestic consumption contexts. In contrast, the site of Cinco Santos II (CSII) is a small rural obsidian workshop site operating 


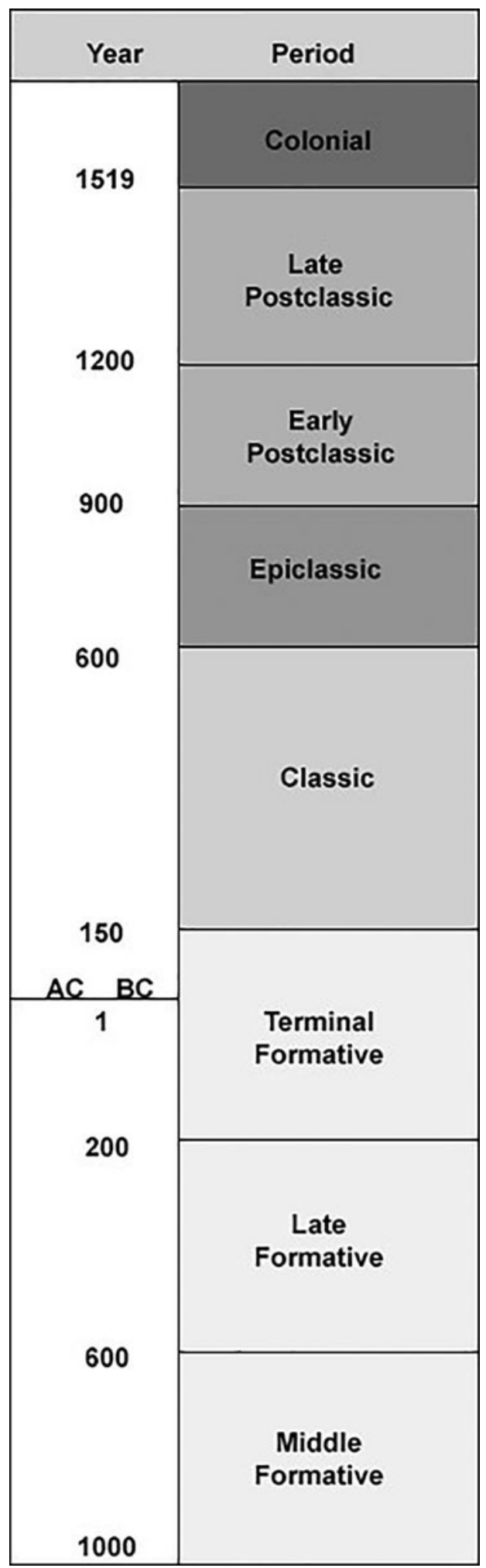

Figure 3. Central Mexico chronology. during the Late Postclassic where obsidian was imported and used to produce products that were distributed and consumed within the Tlaxcala region. Together they supply a profile of obsidian use and consumption at two different scales, providing a baseline to evaluate whether the proposed economic blockade affected the flow of obsidian sources under Aztec control into the Tlaxcalan heartland.

\section{Methods}

Obsidian geochemical signatures have become a standard way to discuss intra- and interregional relationships between groups and polities (Ebert et al. 2014; Golitko and Feinman 2015; Hirth et al. 2000; Millhauser et al. 2015; Moholy-Nagy et al. 2013). Shifts in source utilization often signal changes in access, ideology, or preference for a particular obsidian source; the trade relationships through which they moved; or changes in the centers that dominated their exploitation. Distance to an obsidian source is not the only important factor in resource provisioning; social networks also play a key role. Visualizing the movement of goods across the landscape provides information about linkages between regions, although archaeologists must reconstruct the socioeconomic mechanisms through which obsidian moved. Recent explorations of subsource variability have shed light on past geopolitical frameworks and levels of source exploitation (Millhauser et al. 2017; Vicencio 2019).

Obsidian sources in this study were identified by combining portable X-ray fluorescence (pXRF) of gray obsidian using a Bruker Tracer III-SD with visual identification of green obsidian assigned to the Sierra de las Navajas source. Obsidian artifacts from the workshop site of CSII were analyzed in the Laboratorio Nacional de Ciencias para la Investigación y la Conservación del Patrimonio Cultural in the Physics Department at the Universidad Nacional Autónoma de México under the supervision of José Luis Ruvalcaba Sil. The Bruker Tracer III-SD was equipped with an X-ray tube with the maximum voltage of $40 \mathrm{kV}$ and a silica detector. The conditions for measurements were processed with a filter of 12 mil AI, $1 \mathrm{mil} \mathrm{Ti}, 6 \mathrm{mil} \mathrm{Cu}, 30 \mu \mathrm{A}$, and 
$40 \mathrm{kV}$. Each sample was run for 60 seconds. The values of parts per million were obtained through calibration of the quantifying coefficient provided by Bruker. Trace elements were interpreted through a reference set provided by Bruker, and the grouping of the elements followed established procedures used by previous studies to enhance reliability (see Supplemental Table 3; Ebert et al. 2014; Millhauser et al. 2015; Tykot 2017).

Obsidian from Tepeticpac and CSII was analyzed using the lithic technology approach (Clark 1982, 1985, 1986, 1987; Healan 2002, 2003; Hirth 2006; Hirth and Flenniken 2002; Hirth et al. 2006; Hruby et al. 2014; Pastrana 2002; Pastrana and Hirth 2003; Santley and Barrett 2002). Lithic artifacts were analyzed for technological attributes and placed within a reduction sequence beginning with the acquisition of raw material and extending to the production of finished artifacts. Final products include obsidian blades, scrapers, and bifaces, as well as production debitage, associated errors, and general expedient flaking (Hirth and Flenniken 2002; Inizan et al. 1999). Reduction sequences can reflect social activities within and surrounding the area of production. Here, we compare obsidian remains recovered in production and consumption contexts to evaluate how changes in obsidian procurement networks affected the distribution of raw material and finished obsidian goods recovered in Tlaxcala. The combined use of technological and source analysis provides a more nuanced view of supply networks and exchange dynamics than either of these approaches used alone (Hirth 2008).

Accelerated mass spectrometry (AMS) radiocarbon $\left({ }^{14} \mathrm{C}\right)$ dating of charcoal and organic material was conducted at the Human Paleoecology Isotope Geochemistry Laboratory at Penn State. Samples were processed for ${ }^{14} \mathrm{C}$ dating using an acid-base-acid (ABA) procedure described by Kennett and colleagues (2017). After removing adhering sediment, $20 \mathrm{mg}$ of each sample was subjected to alternating $\mathrm{ABA}$ washes in $1 \mathrm{~N} \mathrm{HCL}$ and $1 \mathrm{~N} \mathrm{NaOH}$ at $70^{\circ} \mathrm{C}$ for 20 minutes to dissolve carbonate contamination. The repeated base washes extracted humates accumulated from soil organic matter. A final acid wash removed secondary carbonates formed during the base treatment. After this procedure, samples were returned to neutral $\mathrm{pH}$ with two 20 -minute baths in deionized (DI) water at $70^{\circ} \mathrm{C}$ to remove chlorides. Samples were combusted for three hours at $900^{\circ} \mathrm{C}$ in vacuum-sealed quartz tubes with $\mathrm{CuO}$ powder and $\mathrm{Ag}$ wire to produce sample $\mathrm{CO}_{2}$. Samples were then reduced to graphite at $550^{\circ} \mathrm{C}$ using $\mathrm{H}_{2}$ and $\mathrm{Fe}$ catalyst, with reaction water drawn off with C-9 $\mathrm{Mg}$ $(\mathrm{ClO} 4)_{2}$ (Santos et al. 2004). At the Penn State Radiocarbon Laboratory, graphite samples were pressed into targets in A1 cathodes and loaded on a target wheel with standards and backgrounds for AMS analysis. Results were corrected for isotopic fractionation according to the conventions of Stuiver and Polach (1977). Dates were then calibrated with OxCal v.4.3.2 (Bronk Ramsey 2013) using the IntCal13 Northern Hemisphere curve (Reimer et al. 2013).

\section{Obsidian Distribution across Central Mexico}

Information about obsidian consumption in Central Mexico comes from excavations at a limited number of sites (Table 1). During the Early Postclassic (AD 900-1200) at Xaltocan, most of the obsidian $(68.9 \%)$ came from the Sierra de las Navajas source. The use of this green obsidian increased over time, climbing to $93.2 \%$ during the Late Postclassic (Millhauser 2005). This is not surprising, because Aztec influence facilitated the movement of Sierra de las Navajas obsidian throughout its territories. At Late Postclassic Chalco, obsidian from the Otumba and Sierra de las Navajas sources constitutes between $78 \%$ and $94 \%$ of the total obsidian assemblage (Elam et al. 2008). The site of Cihuatecpan, in the Teotihuacan Valley, has the lowest proportion of Aztec-controlled sources of obsidian, but this can be attributed to the fact that only green obsidian is reported, with most of the gray obsidian likely originating from Otumba $3 \mathrm{~km}$ to the south (Figure 2). In general, sites in the Basin of Mexico relied heavily on Otumba and Sierra de las Navajas obsidian both before and during Aztec regional influence (Evans 1988).

The consumption of green obsidian varies in the regions surrounding the Basin of Mexico 
Table 1. Distribution of Sierra de las Navajas and Otumba Obsidian Reported in Central Mexico Leading up to and during the Late Postclassic.

\begin{tabular}{|c|c|c|c|c|c|}
\hline Site & Period & Total Obsidian & Pachuca & Otumba & Source \\
\hline \multicolumn{6}{|l|}{ Basin of Mexico } \\
\hline Cihuatecpan $^{\mathrm{a}}$ & LPC & 11,310 & $24.1 \%$ & & Evans 1988:Table 1.2 \\
\hline Chalco & LPC & 18 & $66.7 \%$ & $27.8 \%$ & Elam et al 2008:Table 12.1 \\
\hline Xaltocan & LPC & & $93.2 \%$ & & Millhauser 2005:Table 12.8 \\
\hline Chiconautla & M-LPC & 365 & $82.7 \%$ & & Elson 1999:Table 5 \\
\hline Chalco & MPC & 19 & $72.0 \%$ & $16.0 \%$ & Elam et al 2008:Table 12.1 \\
\hline Xaltocan & MPC & & $89.4 \%$ & & Millhauser 2005:Table 12.8 \\
\hline Xaltocan & EPC & & $68.9 \%$ & & Millhauser 2005:Table 12.8 \\
\hline Chalco & EPI & 83 & $34.0 \%$ & $44.0 \%$ & Elam et al 2008:Table 12.1 \\
\hline Azcapotzalco & EPI & 612 & $10.60 \%$ & & Chávez et al 1990:Table 1 \\
\hline \multicolumn{6}{|l|}{ Morelos } \\
\hline Yautepec & LPC-B & 20,126 & $94.0 \%$ & & Smith 2006:Tables C4-1 to C4-5 \\
\hline Cuexcomate & LPC-B & & $92.8 \%$ & & Earle and Smith 2012:Table 10.6 \\
\hline Capilco & LPC-B & & $95.2 \%$ & & Earle and Smith 2012:Table 10.6 \\
\hline Yautepec & LPC-A & 4,952 & $93.2 \%$ & & Smith 2006:Tables C4-1 to C4-5 \\
\hline Cuexcomate & LPC-A & & $91.0 \%$ & & Earle and Smith 2012:Table 10.6 \\
\hline Capilco & LPC-A & & $95.8 \%$ & & Earle and Smith 2012:Table 10.6 \\
\hline Yautepec & MPC & 2,108 & $93.4 \%$ & & Smith 2006:Tables C4-1 to C4-5 \\
\hline Xochicalco & EPI & 630 & $5.7 \%$ & & Hirth et al 2000:Table 7.4 \\
\hline \multicolumn{6}{|l|}{ Hidalgo } \\
\hline Tula Chico/La Mesa & EPC (Lat & ollan) & $85.0 \%$ & & Healan 2007:Figure 2 \\
\hline Tula Chico/La Mesa & $\mathrm{EPC}(\mathrm{Ea}$ & Tollan) & $60.0 \%$ & & Healan 2007:Figure 2 \\
\hline Cerro Magoni & EPC & & $18.0 \%$ & & Anderson 2018:Ch.8 p.9 \\
\hline Tula Chico/La Mesa & EPI (Cor & & $<10.0 \%$ & & Healan 2007:Figure 2 \\
\hline Cerro Magoni & EPI & 871 & $<10.0 \%$ & & Anderson 2018:Ch.8 p.9 \\
\hline \multicolumn{6}{|l|}{ Toluca Valley } \\
\hline Calixtlahuaca & LPC-B & 707 & $47.5 \%$ & $23.0 \%$ & Huster 2016:Tables 4.10-4.13 \\
\hline Calixtlahuaca & LPC-A & 1,622 & $34.9 \%$ & $21.7 \%$ & Huster 2016:Tables 4.10-4.13 \\
\hline Calixtlahuaca & MPC & 1,249 & $15.5 \%$ & $34.1 \%$ & Huster 2016:Tables 4.10-4.13 \\
\hline Santa Cruz Atizapan & EPI & 4,351 & $8.3 \%$ & $6.9 \%$ & Benitez 2006:Table 6 \\
\hline Santa Cruz Atizapan & $\mathrm{LC}$ & 2,507 & $8.7 \%$ & $5.2 \%$ & Benitez 2006:Table 6 \\
\hline \multicolumn{6}{|l|}{ Puebla-Tlaxcala } \\
\hline Tepeticpac & LPC-B & 2013 & $15.7 \%$ & $10.0 \%$ & Vicencio 2015:77-78 \\
\hline Tepeticpac & LPC & & $15.4 \%$ & & Xiuhtecutli 2018:15 \\
\hline Tlaxcallan & LPC & 1556 & $14.0 \%$ & $2.2 \%$ & Millhauser et al 2015:Table 1 \\
\hline Cinco Santos II & LPC & 1978 & $11.8 \%$ & $4.8 \%$ & \\
\hline La Laguna & LPC & 481 & $5.6 \%$ & & Carballo and Pingarrón $2012^{\mathrm{b}}$ \\
\hline Cholula & $\mathrm{PC}^{\mathrm{c}}$ & 89 & $18.0 \%$ & & Hester et al 1972:Table 1 \\
\hline Cholula & $\mathrm{PC}$ & 158 & $23.4 \%$ & & Edelstein 1995:Table $2^{\mathrm{d}}$ \\
\hline Cholula & EPI & 93 & $17.2 \%$ & & Edelstein 1995:Table $2^{\mathrm{d}}$ \\
\hline Cacaxtla-Xochitecatl & EPI & 3,387 & $12.2 \%$ & & Hirth 2005:Table 3 \\
\hline Cholula & $\mathrm{LC}$ & 261 & $78.2 \%$ & & Edelstein 1995:Table $2^{\mathrm{d}}$ \\
\hline Nealtican & $\mathrm{LC}$ & 73 & $50.7 \%$ & $18.7 \%$ & Hirth 2013:Table 4 \\
\hline Cantona & $\mathrm{CL}^{\mathrm{e}}$ & 73 & $10.0 \%$ & $7.0 \%$ & Tellez Nieto 2013:Gráfico 4 \\
\hline Tetimpa & $\mathrm{TF}$ & 642 & $3.0 \%$ & $73.0 \%$ & Iceland 1995 \\
\hline
\end{tabular}

${ }^{\mathrm{a} O p .} 8$ midden and surface materials not included.

${ }^{\mathrm{b}}$ Contexts sorted through personal communication with David Carballo and Dave Walton.

${ }^{c}$ Data from personal communication with Patricia Plunket at the Universidad de las Americas, Puebla.

${ }^{\mathrm{d}}$ Recalculated by removing non-obsidian lithics from the total.

${ }^{\text {e}}$ Samples come from multiple contexts, with long chronological ranges, thereby making it challenging to determine the time period. Most samples, however, come from the Classic period.

(Table 1). During the Classic period, green obsidian from Sierra de las Navajas and gray obsidian from Ucareo, Michoacan, were the two major sources supplying sites in western Morelos. Ucareo became the dominant source provisioning Xochicalco during the Epiclassic 
(Hirth 2006; Hirth and Angulo 1981). By the Middle Postclassic to Late Postclassic, the sites of Yautepec (Smith 2006), Cuexcomate, and Capilco (Earle and Smith 2012) steadily consumed green obsidian from Sierra de las Navajas, which constituted more than $90 \%$ of any assemblage.

Information on obsidian consumption is limited for the Tula area north of the Basin of Mexico except for the Epiclassic and Early Postclassic periods (Table 1). During the Epiclassic (Prado/ Corral phases, AD 600-800), settlements primarily relied on the Ucareo-Zinapecuaro source located $150 \mathrm{~km}$ to the west. The distribution of green obsidian from Sierra de las Navajas (70 km to the east) at Tula and smaller sites, such as Cerro Magoni, was relatively low $(<10 \%)$. By the Early Postclassic (Late Tollan phase, AD 1000-1100), exploitation of Sierra de las Navajas obsidian increased significantly in Tula $(60 \%-$ $85 \%$ ) but only slightly in Cerro Magoni (18\%; Anderson 2018; Healan 2007, 2012). This variation within the region points to complex exchange networks that greatly influenced access to obsidian sources.

In the Toluca Valley, the consumption of obsidian sourced from Sierra de las Navajas and Otumba increased steadily over time (Table 1). During the Classic and Epiclassic, the quantity of obsidian from these sources at Santa Cruz Atizapan was low, ranging between $13 \%$ and $15 \%$ (Benitez 2006). At Calixtlahuaca, the frequency of these two sources rose from 49.65\% during the Middle Postclassic to $56.54 \%$ and, eventually, $70.46 \%$ by the end of the Late Postclassic (Huster 2016). This steady growth of Sierra de las Navajas and Otumba obsidian points to the increase of trade between the Basin of Mexico and the Toluca Valley throughout the Postclassic.

What is important here is that the frequency of green obsidian from Sierra de las Navajas remained relatively steady in the Puebla-Tlaxcala region (Table 1). During the Classic period, information from Cholula and the site of Nealtican indicates that the southern Valley of Puebla was largely provisioned with green obsidian from Sierra de las Navajas, which constituted between $50 \%$ and $78 \%$ of lithic assemblages (Edelstein 1995; Hirth 2013). In the northeastern part of the region at Cantona, green obsidian only made up $10 \%$ of the overall assemblage (Tellez Nieto 2013). This is a result, no doubt, of Cantona's location adjacent to the ZaragozaOyameles obsidian source that met most of its obsidian needs (Figure 2). The quantity of green obsidian arriving in central Puebla-Tlaxcala declined during the Epiclassic to between 12\% and $19 \%$ at Xochitecatl-Cacaxtla and Cholula, when the former grew into a powerful regional center and the latter was partially abandoned (Edelstein 1995; Hirth 2005; Plunket and Uruñuela 2018). During the Middle to Late Postclassic periods, the Puebla-Tlaxcala Valley was largely under the influence of the three altepemeh of Tlaxcala, Cholula, and Huexotzinco. Throughout the Postclassic, obsidian in the form of macrocores, polyhedral cores, and finished blades entered the region from a variety of sources. During the Late Postclassic it constituted only $5.6 \%$ of the obsidian assemblage at La Laguna, Tlaxcala, and 14\%-16\% of assemblages at Tepeticpac and other sites in the Tlaxcalan confederacy. At Cholula, green obsidian ranged from $18 \%$ to $23 \%$ for undifferentiated Postclassic deposits (Edelstein 1995). Consequently, Sierra de las Navajas remained a relatively secondary resource of obsidian in the PueblaTlaxcala region.

\section{Obsidian Consumption in Late Postclassic Tepeticpac, Tlaxcala}

The altepetl of Tepeticpac is the oldest of the four central señorios within the Tlaxcalan confederacy (López et al 2016). Tepeticpac was first occupied during the Epiclassic when it had a small residential population (López et al. 2016; Muñoz Camargo 1892 [1576-1595]:53-54). As the first of the four señorios, Tepeticpac is located on a defensible hilltop (Figure 3) and was a major military center within the Tlaxcalan confederacy compared to the other three señorios of Tizatlan, Ocotelulco, and Quiahuiztlan (Aguilera 1991:32; López and Santacruz 2010; Muñoz Camargo 1892 [1576-1595]:103). Tepeticpac's large public spaces, absence of luxurious elite palaces, and lack of iconography elevating a single individual or lineage have been used as evidence for communal or corporate leadership (Fargher et al. 2010, 2011, 2017; López et al. 
2016, 2019). Tepeticpac was a large center that exerted considerable influence over the PueblaTlaxcala region. Its ceramic assemblage is different from that of neighboring Cholula and reflects a regional tradition shared by other sites within the Tlaxcalan domain. Tepeticpac's regional prominence made it an important center of obsidian consumption during the Late Postclassic (Millhauser et al. 2015; Vicencio 2015; Xiuhtecutli 2018).

Archaeological excavations conducted in 2012 by Aurelio López and Ramón Santacruz Cano uncovered an elite residence, labeled CA-2 (Figure 3), near the summit of Tepeticpac (López and Santacruz 2015). The compound was a multiroom residence with partially intact stucco floors for three rooms connected by a hallway, one platform, and an external patio (Figure 4). The residence was occupied primarily during the Late Postclassic period as Tepeticpac rose to power; it continued to be occupied throughout the period of the supposed Aztec trade embargo and into the early colonial period. It was inhabited during Spanish contact, and its occupants would have been witnesses to and likely participants in the events of the conquest between AD 1519 and 1521.

Two mass spectrometer (AMS) radiocarbon $\left({ }^{14} \mathrm{C}\right)$ assays from the Late Postclassic occupation were analyzed from this structure (Figure 5). The first sample dates to $435 \pm 15 \mathrm{BP}$ (PSUAMS-2715; charcoal). The $2 \sigma$ calibrated age range is cal AD 1433-1464. The second sample dates to $330 \pm 15$ BP (PSUAMS-2717; seed) and has two possible $2 \sigma$ calibrated age ranges; cal AD 1490-1603 (77.1\%) and cal AD 1613-1637 (18.3\%). Because the analyzed obsidian comes from a precontact level below the early colonial structure, we believe that the date falls within the former calibrated age range and very likely represents only prehispanic material (López et al. 2020).

The obsidian from CA-2 consists primarily of finished pressure blades (73.1\%). The obsidian debitage recovered from Late Postclassic levels indicates that a small amount of in-residence craft production was practiced at CA-2 consisting of obsidian biface and pressure blade production (Vicencio 2015:Table 19; Supplemental Table 1). Almost $16 \%$ of the obsidian assemblage consisted of green obsidian, which geochemical analysis has confirmed originated from Sierra de las Navajas (Supplemental Table 3). All the percentages discussed here and throughout this article are expressed in counts of artifacts.

Geochemical analysis was conducted on a random sample of 178 pieces of gray and black obsidian using pXRF to determine the other sources used to produce finished artifacts within the workshop. The results of these 178 determinations are presented in Supplemental Table 1 with the percentage of assemblage adjusted for the visual identification of Sierra de las Navajas pieces and summarizing all the obsidian sources represented in the collection. Obsidian from Paredón, Puebla, constitutes $59.2 \%$ of the collection. Three other gray obsidian sources are represented: Zaragoza-Oyameles, Puebla (12.8\%); Otumba, Mexico (9.0\%); and Pico de Orizaba, Puebla (3.3\%; Vicencio 2015:Table 19). These findings appear comparable to those reported elsewhere in Tlaxcala. All four señorios-Tepeticpac, Ocotelulco, Quiahuiztlan, and Tizatlan-report percentages of obsidian from Sierra de las Navajas at about $14 \%$ by count and $12 \%$ by weight (Millhauser et al. 2015; Xiuhtecutli 2018; see Table 1). Overall, Tepeticpac and its surrounding señorios obtained approximately $15 \%$ of their obsidian from the Aztec-controlled source of Sierra de las Navajas during the Late Postclassic period. When the Otumba source is included, the quantity of obsidian derived from Aztec-controlled sources rises to approximately one-quarter of all obsidian consumed at Tepeticpac. The ${ }^{14} \mathrm{C}$ date of the CA-2 residence also makes it contemporaneous with the small rural obsidian workshop excavated at the Cinco Santos II site.

\section{Obsidian Consumption and Production at Cinco Santos II}

The site of Cinco Santos II (CSII) was located during the Proyecto Regional de Sitios Secundarios in Puebla-Tlaxcala (Gentil 2018). It falls within the Tlaxcalan confederacy and is located on a slope overlooking the valley corridor that connects the Puebla-Tlaxcala Valley with the Basin of Mexico (Figure 1). This corridor was an important communication route between Central Mexico and the Gulf coast (Carballo and Pluckhahn 2007; García Cook 1981). If an 


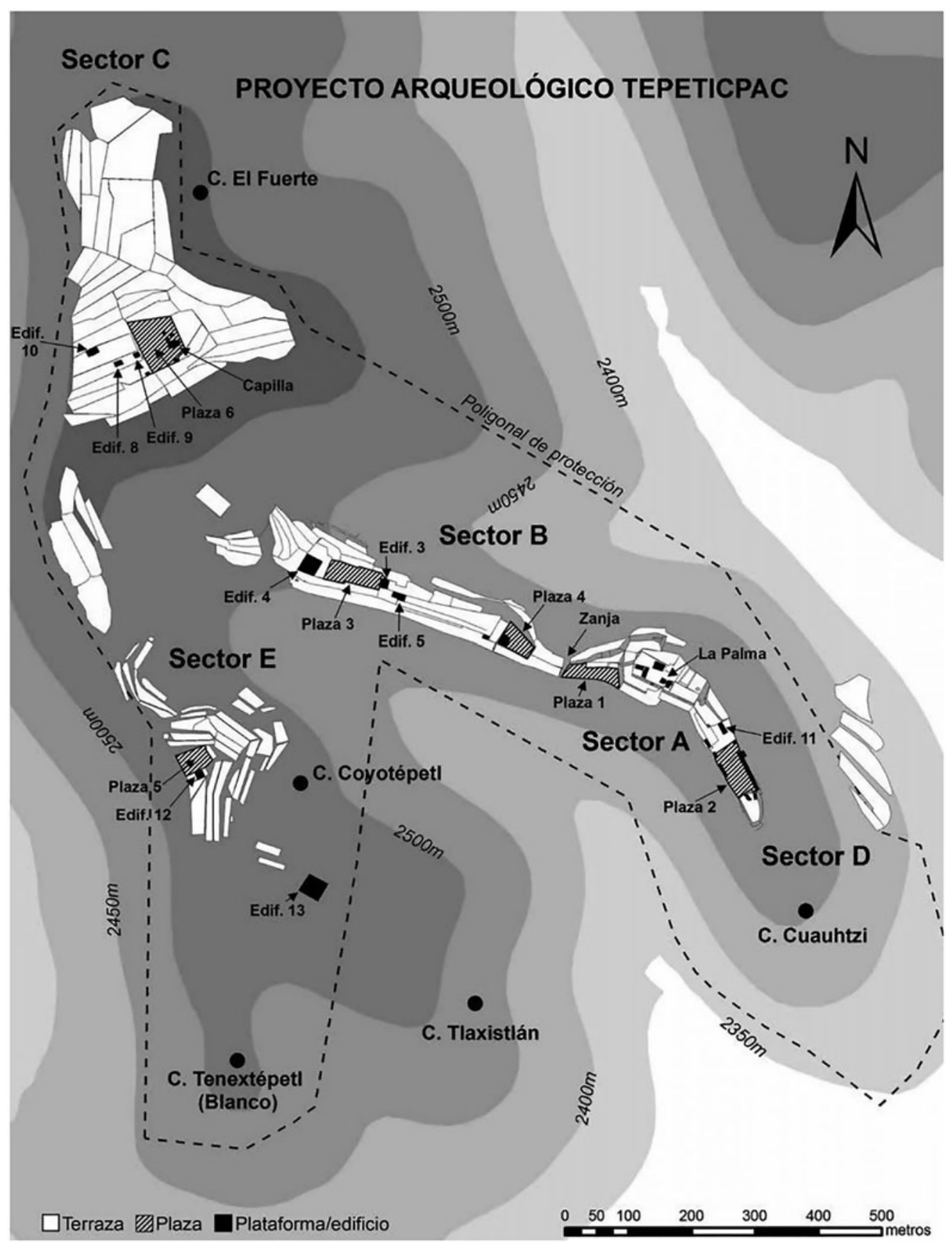

Figure 4. Map of Tepeticpac and location of CA-2 excavation (López et al. 2015:Figure 2).

embargo existed, this route would have been closely monitored to prevent the flow of goods into Tlaxcala.

CSII is a domestic site approximately 3 ha in size, located on a hillslope $14 \mathrm{~km}$ north of
Tepeticpac and $1 \mathrm{~km}$ north of the Late Postclassic Tlaxcalan village site of Tlixpa. Obsidian production debitage was widespread, indicating that many of its households were involved in obsidian craft production. If raw materials were 


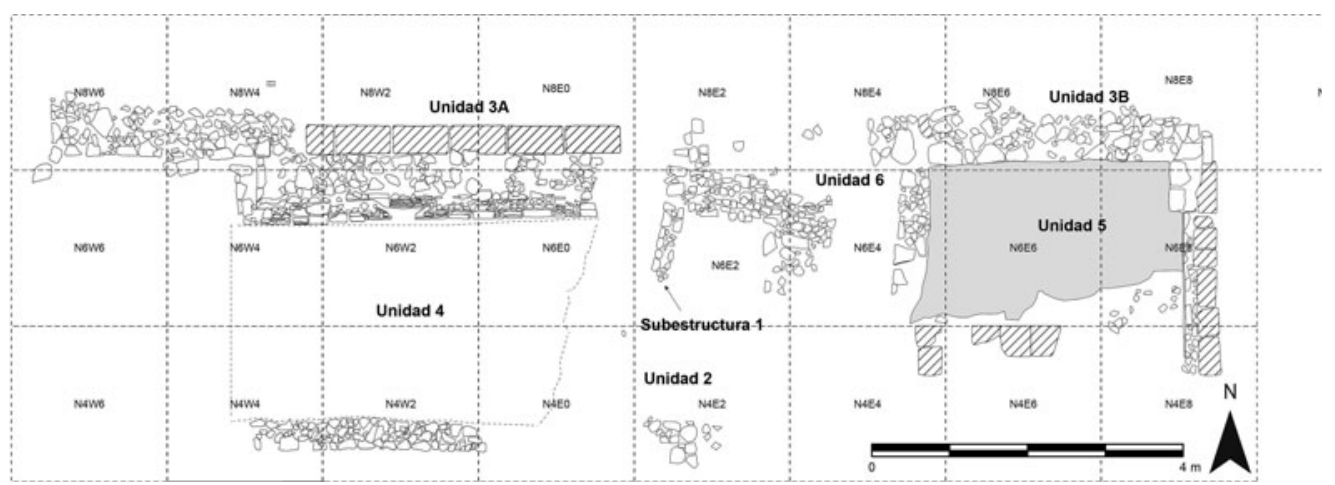

Figure 5. Late Postclassic / contact period excavation map from CA-2 (Vicencio 2015:Figure 8).

moving through commercial exchange networks, CSII's location along the natural transportation corridor into and out of the Basin of Mexico would have provided good access to obsidian from Otumba and Sierra de las Navajas, located $60 \mathrm{~km}$ and $95 \mathrm{~km}$ to the northwest, respectively. Conversely, we would expect these two sources to yield low percentages at CSII if the Aztec embargo were effective in restricting the flow of Basin of Mexico goods into Tlaxcala, especially because the source of Paredón is only $45 \mathrm{~km}$ north of the site.

Two areas were excavated at CSII, a domestic structure associated with an obsidian workshop and a small open platform that may have been a public assembly area. AMS radiocarbon dates were run on charcoal from sealed contexts in each area (Figure 5). This analysis established that CSII was a single-period occupation site that dated to the end of the Late Postclassic. The AMS ${ }^{14} \mathrm{C}$ date from the domestic workshop was $480 \pm 20$ BP (PSUAMS-6413), which produced a $2 \sigma$ calibrated age range of cal $A D$ 1416-1446. The AMS ${ }^{14} \mathrm{C}$ date from the open platform was $455 \pm 20$ BP (PSUAMS-6412) producing a $2 \sigma$ calibrated age range of cal AD 1420 1455 (Figure 6). The calibrated ranges of both these dates place them prior to or shortly after the implementation of the proposed embargo.

We recognize the difficulty of using radiocarbon methods to date archaeological remains to only a 60 - to 70 -year period. It should be noted that both CSII dates were from charcoal from posts, which raises the "old wood" issue for consideration; the trees used for the structure were cut 15-20 years before its final occupation (Dean 1978; Schiffer 1986). This implies that CSII closely aligns with the period of AztecTlaxcala conflict. Ceramics recovered at CSII place the occupation of the site to the very end of the Late Postclassic period. Like CA-2, CSII also has a low percentage of early colonial ceramics in its assemblage, suggesting that it was occupied contemporaneously with Aztec-

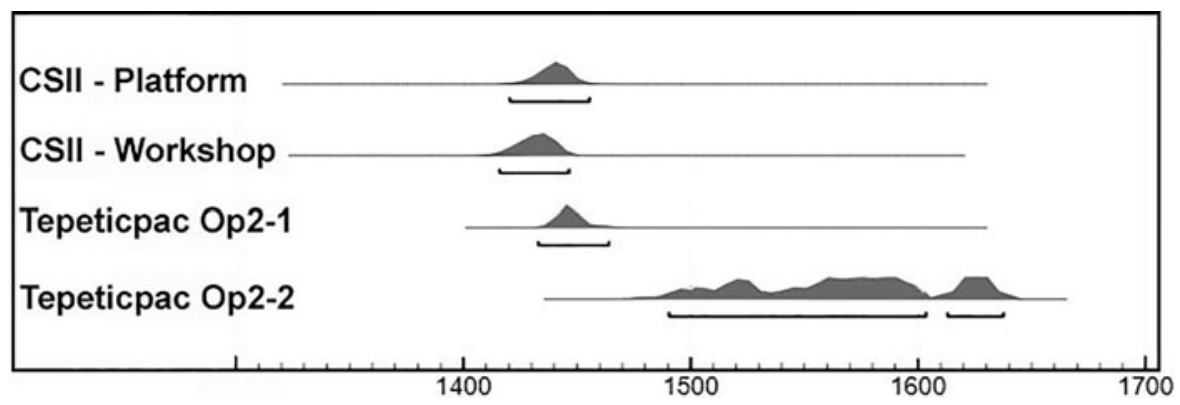

Figure 6. AMS calibrated dates. OxCal v4.3.2 Bronk Ramsey (2017); r5 IntCal13 atmospheric curve (Reimer et al. 2013). 
Tlaxcalan aggression and the proposed embargo. Given that obsidian was fundamental to the production of weaponry, we expect that it would have been a prime resource targeted by an economic embargo. Ethnohistorical sources indicate that Tenochtitlan seized control of towns near and leading to the Sierra de las Navajas source from Texcoco, which suggests it wanted to restrict access to the source, even by their allies (Pastrana and Carballo 2017:Figure 22.1).

All the obsidian (1,978 pieces) collected from survey and excavations was analyzed using the lithic technology approach and assigned to the respective stage of production (Table 2). The primary production activity was the manufacture of obsidian prismatic blades. A total of $61.7 \%$ of the production debris was associated with blade manufacture, which included percussion core shaping (15.2\%), pressure core shaping (15.9\%), and final blade production (27.9\%). The presence of corner blades and half-cylindrical core fragments in the assemblage indicates that craftspeople at CSII used both progressive and sequential core-reduction techniques to produce prismatic blades (Hirth et al. 2020). General percussion flaking and some bifacial and unifacial production were also practiced (16.7\%). Undiagnostic small flakes and flake shatter $(21.7 \%)$ were recovered as well. The production activities identified reflect general-purpose production where obsidian blades were produced alongside expedient flakes and a few bifaces and unifaces.

Table 2 separates green and gray obsidian into their respective technological categories. Technological analysis indicates that obsidian entered the workshop as both shaped macrocores and unworked nodules. The full range of coreshaping debitage using percussion and pressure techniques was recovered, indicating that macrocores had a small amount of cortex on one or more of their lateral surfaces. Unshaped nodules were used for both general percussion flaking and shaping a few bifaces and unifaces.

Source analysis was conducted as a two-step process. First, the amount of green obsidian, $11.8 \%$ of the CSII collection, was identified visually and confirmed as originating from Sierra de las Navajas with geochemical analysis (Supplemental Table 3). Second, geochemical analysis was then conducted on a sample of 148 gray

Table 2. Detailed CSII Obsidian Analysis of All Obsidian Organized by Technology and Differentiated between Green and Gray.

\begin{tabular}{|c|c|c|c|c|c|}
\hline Stage of Production & Subclass & Gray & Green & Total & $\%$ \\
\hline \multirow[t]{2}{*}{ Percussion core shaping } & Decortication blades \& flakes & 132 & 5 & 137 & 6.9 \\
\hline & Percussion blades \& flakes & 134 & 30 & 164 & 8.3 \\
\hline \multirow[t]{3}{*}{ Pressure removals } & Initial Series pressure blades & 182 & 42 & 224 & 11.3 \\
\hline & Corner blades & 89 & 2 & 91 & 4.6 \\
\hline & Final series prismatic blades & 468 & 84 & 552 & 27.9 \\
\hline \multirow[t]{3}{*}{ Other core-blade products } & Blade artifacts & 2 & 0 & 2 & 0.1 \\
\hline & Blade production byproducts & 20 & 5 & 25 & 1.3 \\
\hline & Blade core fragments & 25 & 0 & 25 & 1.3 \\
\hline Total core-blade debitage & & 1,052 & 168 & 1,220 & 61.7 \\
\hline \multirow[t]{3}{*}{ General percussion } & Percussion flakes & 73 & 11 & 84 & 4.3 \\
\hline & Bipolar flakes & 9 & 0 & 9 & 0.5 \\
\hline & Nodules \& raw material & 2 & 0 & 2 & 0.1 \\
\hline \multirow[t]{4}{*}{ Biface and unifacial shaping } & Bifacial thinning flakes & 79 & 11 & 90 & 4.6 \\
\hline & Pressure flakes & 122 & 19 & 141 & 7.1 \\
\hline & Bifaces & 2 & 0 & 2 & 0.1 \\
\hline & Unifaces & 0 & 1 & 1 & 0.1 \\
\hline Total percussion debitage & & 287 & 42 & 329 & 16.7 \\
\hline \multirow[t]{3}{*}{ Undiagnostic debitage } & Decortication shatter & 79 & 2 & 81 & 4.1 \\
\hline & Small flake fragments & 79 & 0 & 79 & 4.0 \\
\hline & Flake shatter & 248 & 21 & 269 & 13.6 \\
\hline Total undiagnostic debitage & & 406 & 23 & 429 & 21.7 \\
\hline Total obsidian debitage & & 1,745 & 233 & 1,978 & 100.0 \\
\hline
\end{tabular}


obsidian artifacts using pXRF to determine the geological sources represented in the remaining gray obsidian sample. Four separate sources are represented in the gray obsidian: Paredón, Zaragoza, Otumba, and Pico de Orizaba. As can be seen in Table 3, Paredón is the dominant source. The obsidian from four of these sources, including Sierra de las Navajas, appears to have entered the workshop both as preformed macrocores for blade production and as small unworked nodules for bifacial general percussion reduction (Table 3). The same may also have been true of the Pico de Orizaba obsidian, although the sample is too small to determine whether this was the case.

The proportions of gray obsidian were then applied to the whole obsidian assemblage used in the CSII workshop during the Late Postclassic. These adjusted totals are presented in Table 3. Obsidian from Paredón constitutes $60.2 \%$ of the raw material reduced in workshop contexts, followed by obsidian from Zaragoza-Oyameles at $21.4 \%$. The Valley of Mexico sources of Sierra de las Navajas (11.8\%) and Otumba (4.8\%) together represent $16.2 \%$ of the obsidian. Obsidian from the distant Pico de Orizaba occurs as trace amounts at $1.8 \%$ of the assemblage. The question that remains is this: What do the obsidian consumption and production data from Tepeticpac and CSII reflect about general economic patterns and the trade embargo believed to have been imposed on Tlaxcala by the Aztec state?

\section{Discussion}

The obsidian information recovered from Tepeticpac and CSII provides complementary pictures of obsidian provisioning in Tlaxcala at the very end of the Late Postclassic period. The CA-2 excavation at Tepeticpac uncovered a contact period residence of a high-ranking family that continued to be occupied into the early colonial period. Analysis of the lithic technology from CA-2 reflects a household that consumed large numbers of obsidian blades, produced a few bifaces for military armament and other activities, and used percussion flakes in addition to obsidian blades for cutting activities. The presence of both macroblades and narrow percussion blades in the collection indicates that household residents probably had access to some macrocores or polyhedral cores, although it is unclear how much reduction was carried out within the household.

CSII was a small rural obsidian workshop, and meeting its provisioning needs was

Table 3. CSII Obsidian Technological Analysis of 148 Obsidian Pieces Sourced via pXRF.

\begin{tabular}{|c|c|c|c|c|c|c|c|}
\hline Stage of Production & Subclass & $\begin{array}{l}\text { Sierra de las } \\
\text { Navajas* }\end{array}$ & Otumba & Paredón & Zaragoza & $\begin{array}{l}\text { Pico de } \\
\text { Orizaba }\end{array}$ & $\begin{array}{c}\text { Total } \\
\text { Obsidian }\end{array}$ \\
\hline \multirow[t]{2}{*}{$\begin{array}{l}\text { Percussion core } \\
\text { shaping }\end{array}$} & $\begin{array}{l}\text { Decortication blades \& } \\
\text { flakes }\end{array}$ & & 1 & 24 & 3 & & 28 \\
\hline & $\begin{array}{l}\text { Initial series pressure } \\
\text { blades }\end{array}$ & & 2 & 11 & 6 & & 19 \\
\hline \multirow[t]{3}{*}{ Pressure removals } & Corner blades & & & 6 & & & 6 \\
\hline & Final series blades & & 2 & 40 & 12 & 2 & 56 \\
\hline & $\begin{array}{l}\text { Blade production } \\
\text { byproducts }\end{array}$ & & & 1 & & & 1 \\
\hline $\begin{array}{l}\text { Other core-blade } \\
\text { products }\end{array}$ & Blade core fragments & & & 4 & 3 & & 7 \\
\hline General percussion & Percussion flakes & & 1 & 6 & 2 & & 9 \\
\hline Biface shaping & Bifacial thinning flakes & & 1 & 5 & 8 & 1 & 15 \\
\hline $\begin{array}{l}\text { Undiagnostic } \\
\text { debitage }\end{array}$ & Decortication shatter & & 1 & 4 & 2 & & 7 \\
\hline $\begin{array}{l}\text { Total obsidian } \\
\text { debitage }\end{array}$ & & & 8 & 101 & 36 & 3 & 148 \\
\hline \multicolumn{2}{|c|}{ Percentage of the gray obsidian assemblage } & & $5.4 \%$ & $68.2 \%$ & $24.3 \%$ & $2.0 \%$ & $100 \%$ \\
\hline \multicolumn{2}{|c|}{ Percentage of the total obsidian assemblage } & $11.8 \%$ & $4.8 \%$ & $60.2 \%$ & $21.4 \%$ & $1.8 \%$ & $100 \%$ \\
\hline
\end{tabular}

* See Table 2 for technological categories for Sierra de las Navajas. 
fundamental to its operation. Technological evidence indicates that it engaged in the manufacture of obsidian blades alongside a small amount of flake percussion and biface manufacture. Geochemical analysis reveals that this workshop was provisioned with raw material from five obsidian sources. Paredón and ZaragozaOyameles were the two primary sources, which together provided $81.6 \%$ of the obsidian entering the workshop. Present in lesser amounts was obsidian from Sierra de las Navajas (11.8\%), Otumba (4.8\%), and Pico de Orizaba (1.8\%). What is particularly noteworthy is that the five obsidian sources identified at the CSII workshop are the same sources recovered in the CA-2 residence at Tepeticpac (see Table 2 and Supplemental Table 1). Although we cannot determine whether CSII produced and distributed goods at Tepeticpac, the two sites provide a view of obsidian consumption within Tlaxcala at different ends of the provisioning spectrum: CSII at the level of crafting supply (Hirth 2008) and CA-2 as an example of domestic consumption. In both cases obsidian from Paredón, Puebla, was the dominant material used to fashion obsidian tools.

Archaeological evidence shows that the Otumba and Sierra de las Navajas obsidian sources played an important role in provisioning sites in the Basin of Mexico from the Early Formative onward (Johnson and Hirth 2019). Although both were significant sources, obsidian from Sierra de las Navajas became increasingly important from the Classic period onward, eventually dominating lithic assemblages within the Basin of Mexico and Morelos during the Middle and Postclassic periods (Table 1). The PueblaTlaxcala region reflects a different story. Although obsidian from Otumba and Sierra de las Navajas entered the region throughout its history, it did so in small to moderate amounts depending on the time period. More important throughout the region's development was obsidian obtained from Paredón (Supplemental Table 2). Beginning during the Middle Formative period, Paredón supplied a good deal, if not most, of the obsidian consumed in sites throughout the Puebla-Tlaxcala Valley. Recent geochemical analysis provides a breakdown of the obsidian sources used in sites during the Formative period (Supplemental Table 2). The predominance of Paredón obsidian at both CA-2 and CSII before Spanish contact reflects the operation of a long-standing obsidian provisioning network that stretched back into the Formative period. Had a trade embargo of obsidian been initiated, it would have been difficult to restrict access to Paredón and Zaragoza-Oyameles obsidian sources, because they were part of traditional commercial networks that extended far back in time. Moreover, the quantity of obsidian arriving at Puebla-Tlaxcala from the Sierra de las Navajas source seems to have remained relatively unchanged from the Epiclassic into the Late Postclassic.

Although this research focused on obsidian as a critical resource that would have been only one element of an embargo, it is also interesting that a few Basin of Mexico ceramics entered the Puebla-Tlaxcala region. At CSII $1.5 \%$ of the ceramic assemblage consists of three primary imports from Basin of Mexico: Aztec Black on Orange, Texcoco Black on Red, and Texcoco Black and White on Red. At Tepeticpac these three types represent $7.4 \%$ of the ceramic assemblage, although most appear to be local tradeware imitations (Xiuhtecutli 2018). It is unlikely that local populations in Tlaxcala would want ceramic service ware that reflected contact with the Basin of Mexico if the Aztecs had imposed a crushing economic embargo across the region. It is more probable that these ceramics, like obsidian, were moving through normal commercial networks into and across Puebla-Tlaxcala.

\section{Conclusions}

Investigating the possibility of an Aztec trade embargo on Tlaxcala is a fascinating and perplexing endeavor. It is fascinating because, if true, it would imply the use of economic policy to weaken an opponent much like the way that economic sanctions are used against political rivals in our current geopolitical climate. The use of economic sanctions would imply the existence of a highly commercialized landscape where the disruption of economic transactions could have a significant impact on the sociopolitical organization of prehispanic groups. It is perplexing because of the difficulty in isolating a 60- to 70-year interval over which an embargo may 
have been imposed, even when using highprecision ${ }^{14} \mathrm{C}$ dating. Typically, archaeologists are not fortunate enough to have calibrated dates that fall within a narrow time span of less than 100 years.

Information from recent contact period occupations at Tepeticpac and Cinco Santos II provides a useful basis for comparison. The data suggest that if there was an attempt to restrict access to obsidian and other goods entering the Tlaxcala region during the period of the Triple Alliance, it was ineffective. The quantity of obsidian from the Sierra de las Navajas source recovered at Tepeticpac and Cinco Santos II is virtually the same as found at other sites throughout the Puebla-Tlaxcala region from the Epiclassic period onward (Table 1). This reinforces the study by Millhauser and colleagues (2015) that identified obsidian from Aztec-controlled sources in surface collections at several Postclassic sites within the Tlaxcalan domain. The embargo may have been a good talking point for Motecuhzoma II, but the type and quantity of obsidian entering the region remained relatively unchanged over the length of the Postclassic period. Obsidian provisioning most likely was the product of long-standing and independently operating commercial networks that provided for regional provisioning needs independent of any political control or influence.

Future work is needed to test the reality of the embargo using other materials. Cotton is one resource that is included in the list of embargo goods and could be examined using changes in spindle whorl frequencies for spinning cotton and maguey textiles (e.g., Ibarra et al. 2018). Nevertheless, the available data suggest that the Aztec embargo on Tlaxcala was more fiction than fact. Muñoz Camargo (1892 [15761595]:123-124) is the primary sixteenth-century source for Tlaxcala. He ridiculed the idea that the Aztecs kept Tlaxcala as "quails in a cage" for their military exploits and to provide sacrificial victims for Aztec ceremonies. Obsidian was a vital resource, but the information provided here suggests that even if a trade embargo were enacted, it was not effective in isolating Tlaxcala from trade networks that moved obsidian and other daily goods throughout Central Mexico prior to Spanish contact.
Acknowledgments. This research was completed with the involvement of several departments at Penn State: Anthropology, Latin American Studies, Global Studies, and the Liberal Arts Graduate program. We are extremely grateful to the Centro INAH Tlaxcala and Dr. Aurelio López Corral for their continuous collaboration. Geochemical sourcing was supported by grants LN279740, LN293904, LN299076, and CB239609 from CONACYT and IN112018 from PAPIIT UNAM and was carried out in the Laboratorio Nacional de las Ciencias para la Investigación y Conservación del Patrimonio Cultural at the Instituto de Física of the Universidad Nacional Autónoma de México. We thank Drs. José Luis Ruvalcaba Sil, Edgar Casanova González, and Alejandro Mitrani Viggiano for graciously providing access and permission to analyze obsidian from CSII. Finally, we would like to acknowledge Dr. Eric Dyrdahl at Pontificia Universidad Católica del Ecuador for his contributions in developing the standards for identifying the chemical composition of Central Mexican obsidian sources; we also thank Dr. Brendan Culleton and Laurie Eccles at Penn State's AMS Radiocarbon facilities for their support.

Data Availability Statement. All radiocarbon and pXRF data presented in this article can be obtained from ScholarSphere (Penn State): https://doi.org/10.26207/4556-2p42.

Supplemental Materials. Supplemental material for this article is available at https://doi.org/10.1017/laq.2021.31.

Supplemental Table 1. Obsidian Industry and Sourcing at Tepeticpac in the Late Postclassic.

Supplemental Table 2. Obsidian Distribution in PueblaTlaxcala during the Formative Period.

Supplemental Table 3. Raw pXRF Data from CSII.

Supplemental Text 1. pXRF Reference and Obsidian Sampling.

Supplemental Text 2. Reference for Supplemental Table 2.

\section{References Cited}

Aguilera, Carmen

1991 Tlaxcala: Una historia compartida: Los Orígenes, Antropología e Historia. Dirección General de Publicaciones del Consejo Nacional para la Cultura y las Artes, Gobierno del Estado de Tlaxcala, Mexico City.

Anderson, J. Heath

2018 Obsidian Consumption in the Tula Region after Teotihuacan's Decline: A View from Cerro Magoni. In City, Craft, and Residence in Mesoamerica: Research Papers Presented in Honor of Dan M. Healan, edited by Ronald K. Faulseit, Nezahualcoyotl Xiuhtecuhtli, and Haley Holt Mehta, pp. 170-192. Middle American Research Institute, New Orleans, Louisiana.

Benitez, Alexander Villa

2006 Late Classic and Epiclassic Obsidian Procurement and Consumption in the Southeastern Toluca Valley, Central Highland Mexico. PhD dissertation, Department of Anthropology, University of Texas, Austin.

Berdan, Frances F.

2014 Aztec Archaeology and Ethnohistory. Cambridge University Press, Cambridge.

Bronk Ramsey, Christopher

2013 OxCal version 4.2.4. Electronic document, https:// c14.arch.ox.ac.uk/oxcal.html, accessed April 25, 2020. 
2017 OxCal Program, Version 4.3. Oxford Radiocarbon Accelerator Unit, University of Oxford, Oxford.

Bueno Bravo, Isabel

2012 Objetivos económicos y estrategia militar en el imperio azteca. Estudios de Cultura Náhuatl 44:135-163.

Carballo, David M., and Luis Barba Pingarrón

2012 Informe global de proyecto arqueológico de La Laguna, Tlaxcala, 2005-2012. Archivo Técnico del INAH, Mexico City.

Carballo, David M., and Thomas Pluckhahn

2007 Transportation Corridors and Political Evolution in Highland Mesoamerica: Settlement Analyses Incorporating GIS for Northern Tlaxcala. Journal of Anthropological Archaeology 26:607-629.

Chávez, Raul Garcia, Michael D. Glascock, J. Michael Elam, and Harry B. Iceland

1990 The INAH Salvage Archaeology Excavations at Azcapotzalco, Mexico: An Analysis of the Lithic Assemblage. Ancient Mesoamerica 1:225-232.

Clark, John E.

1982 Manufacture of Mesoamerican Prismatic Blades: An Alternative Technique. American Antiquity 47:355-376.

1985 Platforms, Bits, Punches, and Vises: A Potpourri of Mesoamerican Blade Technology. Lithic Technology $14: 1-15$.

1986 Another Look at Small Debitage and Microdebitage. Lithic Technology 15:21-33.

1987 Politics, Prismatic Blades and Mesoamerican Civilization. In The Organization of Core Technology, edited by Jay Johnson and Carol A. Morrow, pp. 259-285. Westview Press, Boulder, Colorado.

Cortés, Hernán

2001 [1520s] Hernan Cortes: Letters from Mexico. Edited and translated by Anthony Pagden. Yale University Press, New Haven, Connecticut.

Dean, Jeffrey S.

1978 Independent Dating in Archaeological Analysis. Advances in Archaeological Method and Theory 1:223-255.

del Castillo, Bernal Díaz

1904 [1568] Historia verdadera de la conquista de Nueva España. Oficina tipográfica de la Secretaría de fomento, Mexico City.

Durán, Francisco

1994 [1588?] The History of the Indies of New Spain. Translated, annotated, and with an introduction by Doris Heyden. University of Oklahoma Press, Norman. Earle, Timothy, and Michael E. Smith

2012 Household Economies under the Aztec and Inka Empires: A Comparison. In The Comparative Archaeology of Complex Societies, edited by Michael E. Smith, pp. 238-284. Cambridge University Press, Cambridge.

Ebert, Claire E., Mark Dennison, Kenneth G. Hirth, Sarah B. McClure, and Douglas J. Kennett

2014 Formative Period Obsidian Exchange along the Pacific Coast of Mesoamerica. Archaeometry 57:54-73.

Edelstein, Ruth Reizel

1995 Obsidian Exploitation and Political Economic Dynamics on the Classic Period through Colonial Era Central Plateau: An Analysis of a Lithic Collection from Cholula, Puebla, Mexico. Master's thesis, Department of Anthropology, McMaster University, Hamilton, Ontario, Canada.

Elam, J. Michael, Michael D. Glascock, and Hector Neff 2008 Obsidian Source Analysis. In Un lugar de jade:
Sociedad y economía en el Antiguo Chalco, edited by Mary G. Hodge, pp. 259-268. Instituto Nacional de Antropología e Historia, Mexico City.

Elson, Christina M.

1999 An Aztec Palace at Chiconautla, Mexico. Latin American Antiquity 10:151-167.

Evans, Susan Toby

2008 Ancient Mexico and Central America: Archaeology and Culture History. Thames and Hudson, New York.

Evans, Susan Toby (editor)

1988 Excavations at Cihuatecpan: An Aztec Village in the Teotihuacan Valley. Publications in Archaeology No. 36. Vanderbilt University, Nashville, Tennessee.

Fargher, Lane F., Richard E. Blanton, and Verenice Y. Heredia Espinoza

2010 Egalitarian Ideology and Political Power in Prehispanic Central Mexico: The Case of Tlaxcallan. Latin American Antiquity 21:227-251.

2017 The Independent Republic of Tlaxcallan. In The Oxford Handbook of the Aztecs, edited by Deborah L. Nichols and Enrique Rodríguez-Alegría, pp. 535542. Oxford University Press, New York.

Fargher, Lane F., Verenice Y. Heredia Espinoza, and Richard E. Blanton

2011 Alternative Pathways to Power in Late Postclassic Highland Mesoamerica. Journal of Anthropological Archaeology 30:306-326.

García Cook, Ángel

1981 The Historical Importance of Tlaxcala in the Cultural Development of the Central Highlands. In Supplement to the Handbook of Middle American Indians: 2. Archaeology, edited by Jeremy A. Sabloff and Patricia A. Andrews, pp. 244-276. University of Texas Press, Austin.

Gentil, Bianca

2018 Proyecto Regional de Sitios Secundarios en PueblaTlaxcala. Informe de la primera temporada de campo 2016 y analices de materiales. Archivo Técnico del INAH, Mexico City.

Golitko, Mark, and Gary M. Feinman

2015 Procurement and Distribution of Pre-Hispanic Mesoamerican Obsidian 900 BC-AD 1520: A Social Network Analysis. Journal of Archaeological Method and Theory 22:206-247.

Hassig, Ross

1988 Aztec Warfare: Imperial Expansion and Political Control. University of Oklahoma Press, Norman.

Healan, Dan M.

2002 Producer versus Consumer: Prismatic Core/Blade Technology at Epiclassic/Early Postclassic Tula and Ucareo. In Pathways to Prismatic Blades: A Study in Mesoamerican Core-Blade Technology, edited by Kenneth G. Hirth and Bradford Andrews, pp. 29-37. Cotsen Institute of Archaeology, University of California, Los Angeles.

2003 From Quarry Pit to the Trash Pit: Comparative CoreBlade Technology at Tula, Hidalgo. In Mesoamerican Lithic Technology: Experimentation and Interpretation, edited by Kenneth G. Hirth, pp. 153-169. University of Utah Press, Salt Lake City.

2007 New Perspectives on Tula's Obsidian Industry and Its Relationship to Chichén Itzá. In Chichén Itzá, Tula and the Epiclassic to the Early Postclassic Mesoamerican World, edited by Jeff Karl Kowalski and Cynthia Kristan-Graham, pp. 429-447. Dumbarton Oaks, Washington, DC. 
2012 The Archaeology of Tula, Hidalgo, Mexico. Journal of Archaeological Research 20:53-115.

Hester, Thomas R., Robert N. Jack, and Robert F. Heizer

1972 Trace Element Analysis of Obsidian from the Site of Cholula, Mexico. Contributions of the University of California Archaeological Research Facility 14:105-110.

Hirth, Kenneth G.

2005 Obsidian Craft Production at Cacaxtla-Xochitécatl, Tlaxcala. Foundation for the Advancement of Mesoamerican Studies report. Electronic document, http:// www.famsi.org/reports/03062/, accessed March 2, 2020.

2006 Obsidian Craft Production in Ancient Central Mexico: Archaeological Research at Xochicalco. University of Utah Press, Salt Lake City.

2008 The Economy of Supply: Modeling Obsidian Procurement and Craft Provisioning at a Central Mexican Urban Center. Latin American Antiquity 19:435-458.

2013 Economic Consumption and Domestic Economy in Cholula's Rural Hinterland, Mexico. Latin American Antiquity. 24:123-148.

Hirth, Kenneth G., Bradford Andrews, and J. Jeffrey Flenniken

2006 A Technological Analysis of Xochicalco Obsidian Prismatic Blade Production. In Obsidian Craft Production in Ancient Central Mexico, edited by Kenneth Hirth, pp. 63-95. University of Utah Press, Salt Lake City.

Hirth, Kenneth G., and Jorge Angulo Villaseñor

1981 Early State Expansion in Central Mexico: Teotihuacan in Morelos. Journal of Field Archaeology 8:135-150.

Hirth, Kenneth G., Omar Espinosa Severino, Nadia Johnson, Bianca Gentil, and Ann Cyphers

2020 Obsidian Craft Production and Progressive CoreBlade Technology in the Central Mexican Highlands. In Olmec Lithic Economy at San Lorenzo, edited by Kenneth Hirth and Ann Cyphers, pp. 288-300. University of Utah Press, Salt Lake City.

Hirth, Kenneth G., and J. Jeffrey Flenniken

2002 Core-Blade Technology in Mesoamerican Prehistory. In Pathways to Prismatic Blades: A Study in Mesoamerican Core-Blade Technology, edited by Kenneth G. Hirth and Bradford Andrews, pp. 121-129. Cotsen Institute of Archaeology, University of California, Los Angeles.

Hirth, Kenneth G., J. Jeffrey Flenniken, and Bradford Andrews

2000 Flaked-Stone Obsidian Tools and their Behavioral Implications. In The Xochicalco Mapping Project, Vol. 2, edited by Kenneth Hirth, pp. 136-150. University of Utah Press, Salt Lake City.

Hirth, Kenneth G., and Deborah L. Nichols

2017 The Structure of Aztec Commerce: Markets and Merchants. In The Oxford Handbook of the Aztecs, edited by Deborah L. Nichols and Enrique Rodríguez-Alegría, pp. 281-298. Oxford University Press, New York.

Hruby, Zachary X., Geoffrey E. Braswell, and Oswaldo Chinchilla Mazariegos (editors)

2014 The Technology of Maya Civilization: Political Economy and beyond in Lithic Studies. Routledge, London.

Huster, Angela

2016 The Effects of Aztec Conquest on Provincial Commoner Households at Calixtlahuaca, Mexico. PhD dissertation, School of Anthropology, Arizona State University, Tucson.
Ibarra, Thania E., Aurelio López Corral, and Ramón Santacruz Cano

2018 The Artisan and the Tool: A TechnologicalFunctional Analysis of Tlaxcallan Spindle Whorls. Archaeometry 60:1221-1236.

Iceland, Harry

1995 The Tetimpa Project (Puebla, Mexico): A Preliminary Analysis of the Lithic Assemblage. Paper presented at the 60th Annual Meeting of the Society for American Archaeology, Minneapolis, Minnesota.

Inizan, Marie-Louise, Michèle Reduron-Ballinger, Hélène Rochey, and Jehanne Féblot-Augustins

1999 Technology and Terminology of Knapped Stone: Followed by a Multilingual Vocabulary Arabic, English, French, German, Greek, Italian, Portuguese, Spanish. Translated by Jehanne Féblot-Augustins. Cercle de recherches et d'études préhistoriques, Nanterre, France. Isaac, Barry L.

1983 The Aztec "Flowery War": A Geopolitical Explanation. Journal of Anthropological Research 39:415432.

Ixtlixóchitl, Fernando de Alva

1965 [ca. 1600] Obras historicas: 2. Historia chichimeca, compiled by Alfredo Chavero. Editorial Nacional, Mexico City.

Johnson, Nadia E., and Kenneth G. Hirth

2019 Altica, Coapexco, and the Role of Middlemen in Formative Obsidian Exchange. Ancient Mesoamerica 30:295-310.

Kennett, Douglas J., Stephen Plog, Richard J. George, Brendan J. Culleton, Adam S. Watson, Pontus Skoglund, Nadin Rohland, Swapan Mallick, Kristin Stewardson, Logan Kistler, Steven A. LeBlanc, Peter M. Whiteley, David Reich, and George H. Perry

2017 Archaeogenomic Evidence Reveals Prehistoric Matrilineal Dynasty. Nature Communications 8:Article 14115. DOI:10.1038/ncomms 14115.

López Corral, Aurelio, Lane F. Fargher, and Ramón Santacruz Cano

2016 La república de Tlaxcallan. Arqueología Mexicana. 139:42-53.

López Corral, Aurelio, Bianca L. Gentil, Lane F. Fargher, Keitlyn Alcantara, and Ramón Santacruz Cano

2020 Anexo 2: Resultados de Fechamientos. In Proyecto Arqueológico Tepeticpac: Informe de la temporada 2012-2018. Archivo Técnico del INAH, Mexico City.

López Corral, Aurelio, and Ramón Santacruz Cano

2010 Tepeticpac: Bastión defensivo de los Texcaltecas del posclásico. In Memoria de las Jornadas de Antropología e Historia de Tlaxcala 2010, pp. 64-70. Centro INAH Tlaxcala, Mexico City.

López Corral, Aurelio, Ivonne Velasco Almanza, Thania E. Ibarra Narváez, and Ramón Santacruz Cano

2019 Iconografía y gobierno colectivo durante el posclásico tardío en Tepeticpac y Tlaxcalan, México. Latin American Antiquity 14:1-21.

López Corral, Aurelio, Manuel Angel Vera Ortiz, Ramón Santacruz Cano, Kenneth G. Hirth, and Eric Dyrdahl

2015 Química o color? Comparación entre el uso de fluorescencia de rayos-X portátil y las técnicas visuales de clasificación de obsidiana de Tepeticpac. Arqueología 50:157-174.

Millhauser, John

2005 Classic and Postclassic Chipped-Stone at Xaltocan. In La producción local y el poder en el Xaltocan Posclásico / Production and Power at Postclassic Xaltocan, 
edited by Elizabeth M. Brumfiel, pp. 267-318. Instituto Nacional de Antropología e Historia, Mexico City; University of Pittsburgh, Pittsburgh, Pennsylvania.

Millhauser, John K., Lindsay Bloch, Mark Golitko, Lane F. Fargher, Neahualcoyotl Xiuhtecutli, Verenice Y. Heredia Espinoza, and Michael D. Glascock

2017 Geochemical Variability in the Paredón Obsidian Source, Puebla and Hidalgo, Mexico: A Preliminary Assessment and Inter-Laboratory Comparison. Archaeometry 60:453-470.

Millhauser, John K., Lane F. Fargher, Verenice Y. Heredia Espinoza, and Richard E. Blanton

2015 The Geopolitics of Obsidian Supply in Postclassic Tlaxcalan: A Portable X-Ray Fluorescence Study. Journal of Archaeological Science 58:133-146.

Moholy-Nagy Hattula, James Meierhoff, Mark Golitko, and Caleb Kestle

2013 An Analysis of pXRF Obsidian Source Attributions from Tikal Guatemala.. Latin American Antiquity 24:72-97.

Muñoz Camargo, Diego

1892 [1576-1595] La Historia de Tlaxcala. Edited by A. Chavero. Bibliotecas de Facsimiles Mexicanos, Guadalajara.

Pastrana, Alejandro

1998 La explotación azteca de la obsidiana en la Sierra de las Navajas. Instituto Nacional de Antropología e Historia, Mexico City.

2002 Variation at the Source: Obsidian Exploitation at Sierra de las Navajas. In Pathways to Prismatic Blades: A Study in Mesoamerican Core-Blade Technology, edited by Kenneth G. Hirth and Bradford Andrews, pp. 15-28. Cotsen Institute of Archaeology, University of California, Los Angeles.

2004 La distribución de la obsidiana de la triple alianza en la Cuenca de Mexico. PhD dissertation, Escuela Nacional de Antropología e Historia, Mexico City.

Pastrana, Alejandro, and David M. Carballo

2017 Aztec Obsidian Industries. In The Oxford Handbook of the Aztecs, edited by Deborah L. Nichols and Enrique Rodríguez-Alegría, pp. 329-341. Oxford University Press, New York.

Pastrana, Alejandro, and Kenneth G. Hirth

2003 Biface Production and Craft Specialization: A View from Sierra de las Navajas, Hidalgo. In Mesoamerican Lithic Technology: Experimentation and Interpretation, edited by Kenneth G. Hirth, pp. 197-207. University of Utah Press, Salt Lake City.

Plunket Nagoda, Patricia, and Gabriela Uruñuela Ladrón de Guevara

2018 Cholula. Fonde de Cultura Economica, Mexico City.

Reimer, Paula J., Edouard Bard, Alex Bayliss, J. Warren Buck, Paul G. Blackwell, Christopher Bronk Ramsey, Caitlin E. Buck, et al.

2013 IntCal13 and Marine13 Radiocarbon Age Calibration Curves 0-50,000 Years cal BP. Radiocarbon 55:1869-1887.

Santley, Robert, and Thomas Barrett

2002 Lithic Technology, Assemblage Variation, and the Organization of Production and the Use of Obsidian on the South Gulf Coast of Veracruz, Mexico. In Pathways to Prismatic Blades: A Study in Mesoamerican Core-Blade Technology, edited by Kenneth G. Hirth and Bradford Andrews, pp. 91-103. Cotsen
Institute of Archaeology, University of California, Los Angeles.

Santos, Guaciara M., John R. Southon, Kevin C. DruffelRodriguez, Sheila Griffin, and Maya Mazon

2004 Magnesium Perchlorate as an Alternative Water Trap in AMS Graphite Sample Preparation: A Report on Sample Preparation at KCCAMS at the University of California, Irvine. Radiocarbon 46:165174.

Schiffer, Michael B.

1986 Radiocarbon Dating and the "Old Wood" Problem: The Case of the Hohokam Chronology. Journal of Archaeological Science 13:13-30.

Smith, Michael E.

2006 Excavaciones de casas postclásicas en la zona urbana de Yautepec, Morelos: informe final. 2 vols. Submitted to Consejo de Arqueología, Instituto Nacional de Antropología e Historia, Mexico City.

Stuiver, Minze, and Henry A. Polach

1977 Discussion Reporting of ${ }^{14} \mathrm{C}$ Data. Radiocarbon 19:355-363.

Tapia, Andrés de

1866 [1500s] Relación hecha por el señor Andrés de Tapia sobre la conquista de México. In Colección de documentos para la historia de México, Vol. 2, compiled by J. García Icazbalceta, pp. 554-594. Antigua Librería, Mexico City.

Tellez Nieto, Alba Lucero

2013 Identificación de la procedencia para obsidianas de Cantona, Puebla, por el método de análisis por activación neutrónica (AAN). Licenciatura thesis, Escuela Nacional de Antropología e Historia, Mexico City.

Tezozómoc, Hernando Alvarado

1878 [1598] Crónica mexicana. In Biblioteca Mexicana edited by José M. Vigil, pp. 223-701. Imprenta y Litografía de Ireneo Paz, Mexico City.

Tykot, Robert H.

2017 A Decade of Portable (Hand-Held) X-Ray Fluorescence Spectrometer Analysis of Obsidian in the Mediterranean: Many Advantages and Few Limitations. MRS Advances 2:1769-1784.

Vicencio Castellanos, Alonso Gabriel

2015 Las navajas en Tepeticpac: Análisis de obsidiana en un conjunto arquitectónico en el sitio de Tepeticpac, Tlaxcala. Licenciatura thesis, Departamento de Antropología, Universidad de las Américas, Puebla, Cholula, Mexico.

2019 El Paredón y Tlaxcala: Un estudio regional de un yacimiento de obsidiana durante el formativo medio y el formativo tardío en Tlaxcala. Master's thesis, Instituto de Investigaciones Antropológicas/Instituto de Investigaciones Sociales, Universidad Nacional Autónoma de México, Mexico City.

Xiuhtecutli, Neahualcoyotl

2018 The Aztec Blockade and Tlaxcalan: Evidence from Tepeticpac. In City, Craft, and Residence in Mesoamerica: Research Papers Presented in Honor of Dan M. Healan, edited by Ronald K. Faulseit, Nezahualcoyotl Xiuhtecuhtli, and Haley Holt Mehta, pp. 227-258. Middle American Research Institute, New Orleans, Louisiana.

Submitted May 17, 2020; Revised July 10, 2020; Accepted March 19, 2021 